\title{
Ozone reservoir layers in a coastal environment - a case study in southern Taiwan
}

\author{
C.-H. Lin ${ }^{1}$, Y.-L. Wu ${ }^{2}$, and C.-H. Lai ${ }^{1}$ \\ ${ }^{1}$ Department of Environmental Engineering and Science, Fooyin University, Kaohsiung, Taiwan \\ ${ }^{2}$ Department of Environmental Engineering, National Cheng-Kung University, Tainan, Taiwan
}

Received: 4 October 2009 - Published in Atmos. Chem. Phys. Discuss.: 21 January 2010

Revised: 25 April 2010 - Accepted: 5 May 2010 - Published: 12 May 2010

\begin{abstract}
The air layer between the nocturnal boundary layer and the top of the daily mixing layer in an ozonepolluted area is known to serve as an ozone reservoir since the ozone that is produced in the mixing layer on the preceding day is effectively preserved throughout the night in the air layer. Ozone reservoir layers existing at night can enhance the accumulation of surface ozone on the following day. However, our knowledge of the characteristics of ozone reservoir layers and their effects on the daily ozone accumulations is limited. In this work, ozone reservoir layers were experimentally investigated at a coastal, near-mountain site in southern Taiwan, $30 \mathrm{~km}$ away from the coastline. Tethered ozone soundings were performed to obtain vertical profiles of ozone and meteorological variables during a four-day ozone episode in November 2006. Observation-based methods are adopted to evaluate the effects of the ozone reservoir layers on the surface ozone accumulation during the fourday ozone episode. Ozone reservoir layers were found to develop every evening with a depth of 1200-1400 m. Ozone concentrations within the reservoir layers reached over 140 parts per billion (ppb). From each evening to midnight, the size of the ozone reservoir layer and the ozone concentration inside dramatically changed. As a result, a concentrated, elevated ozone reservoir layer formed with a depth of $400 \mathrm{~m}$ at $800-1200 \mathrm{~m}$ every midnight. For the rest of each night, the elevated ozone reservoir layer gradually descended until it reached 500-900 $\mathrm{m}$ in the next morning. The observed ozone reservoir layer is formed by the invasion of a cool, marine air mass into a relatively warm, ozone-rich mixing layer in the evening. The descending is related to nocturnal coastal
\end{abstract}

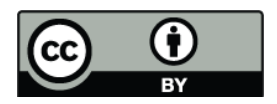

Correspondence to: $\mathrm{C} . \mathrm{-H}$. Lin (chlin@mail.fy.edu.tw) subsidence as well. The ozone concentration at the study site was maximal at 15:00-17:00 LT daily because of the addition of the daily produced ozone on the preceding day. The rate of increase of surface ozone concentration due to the downward mixing of the ozone in the ozone reservoir layers can be as high as $12-24 \mathrm{ppb} / \mathrm{h}$ in the late morning. The contribution of the ozone carried over from the preceding day can be $60-85 \mathrm{ppb}$, which contributes over $50 \%$ to the daily ozone pollution as compared with ozone produced on the study day.

\section{Introduction}

Understanding the processes that drive the ozone accumulations in the boundary layer is important because of the adverse effects of ozone on human health, plants and global warming (Fuhrer, 2003). Surface ozone levels can rise after sunrise from single digits or zero parts per billion $(\mathrm{ppb})$ to more than $120 \mathrm{ppb}$ in the afternoon (National Research Council (NRC), 1991). Processes attributable to the accumulation of ozone can be easily determined from a photochemical trajectory box model (Evans et al., 2000),

$$
\frac{d C}{d t}=\frac{\partial C}{\partial t}+\left(U \frac{\partial C}{\partial x}+V \frac{\partial C}{\partial y}\right)=(P-L C)-C \frac{v_{d}}{h}+\left(C_{r}-C\right) \frac{1}{h} \frac{d h}{d t}
$$

$$
\text { I II III } \quad \text { IV } \quad \text { V } \quad \text { VI }
$$

where $C$ represents the ozone concentration within a considered travelling air box whose vertical height equals a varying mixing height, $h ; U$ and $V$ represent the averaged wind speeds in the $x$ and $y$ directions within the mixing layer; $P$ and $L C$ represent the rates of photochemical production and loss; $v_{d}$ is the dry deposition velocity, and $C_{r}$ is the ozone concentrations above the mixing layer. Notably, $C_{r}$ can be

Published by Copernicus Publications on behalf of the European Geosciences Union. 
regarded as the ozone concentration in an ozone reservoir layer because most of the daily photochemically produced ozone is within the mixing layer. The terms in Eq. (1) represent (1) I, the observed, total rate of variation of ozone concentration variation rate within the travelling air box; (2) II, the observed, total rate of variation of ozone concentration at a specific location $(x, y)$ determined from an Eulerian approach; (3) III, the rate of variation of ozone concentration due to horizontal advection; (4) IV, the rate of variation of ozone concentration due to net photochemical production; (5) $\mathrm{V}$, the rate of variation of ozone concentration due to dry deposition, and (6) VI, the rate of variation of ozone concentration due to net vertical entrainment. Clearly, a positive rate of variation of ozone concentration, as observed at a specific location in the daytime mixing layer, (II), is probably caused by three processes, which are the horizontal advection (III), net photochemical production (IV), and net vertical entrainment (VI).

Emission-based air quality models can be used to calculate explicitly the contributions of the three processes to the daytime accumulation of ozone concentration at a location of interest (Russell and Dennis, 2000). However, the calculated contributions are frequently associated with significant uncertainties, particularly those related to difficulties in acquiring accurate emission inventories (Placet et al., 2000) and effectively simulating boundary layer dynamics (Dabberdt et al., 2004). An alternative method, which couples the measured ozone and its precursors and the dynamics of the boundary layer, is known an observation-based method (Trainer et al., 2000; Cardelino and Chameides, 2000), and can complement emission-based models. $\mathrm{Nu}-$ merous observation-based methods have been developed in the past decade to evaluate photochemical production rates (Trainer et al., 1991, 2000; Cantrell et al., 1996; Spirig et al., 2002; Kleinman, 1986; Cardelino and Chameides, 2000; Gerasopoulos et al., 2006; Frost et al., 1998; Baumann et al., 2000; Shiu et al., 2007). However, no observation-based method has yet been used to analyze the contribution of horizontal advection or vertical entrainment to surface ozone accumulation. This fact is partially explained by the difficulty in simultaneously making vertical measurements of ozone concentration and meteorological variables with a high time resolution. This study develops an observation-based method and applies it to evaluate the contribution of the ozone accumulated owing to vertical entrainments to daily ozone pollution in a field study.

Several investigations have explained the formation of an ozone reservoir layer and its possible enhancement of the surface ozone concentration on the following day (Neu et al., 1994; Stull, 1998; Zhang and Rao, 1999). Figure 1 summarizes these explanations. However, the structures of the ozone reservoir layers are expected to differ from those of the proposed model (Fig. 1). For example, nighttime transport can distort ozone reservoir layers. Several field studies have demonstrated the importance of complicated nighttime

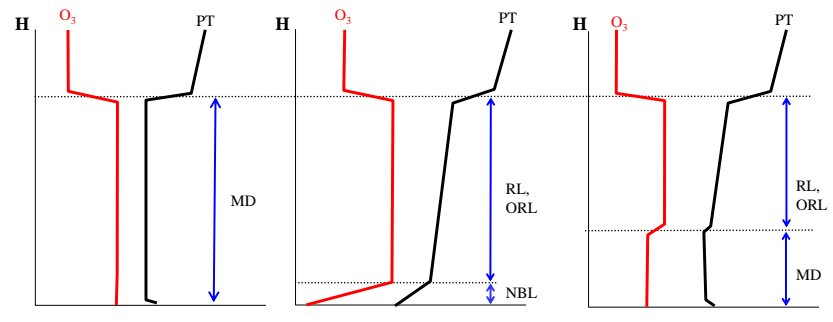

(a) Afternoon

(b) From sunset to next sunrise

(c) Mid-morning

Fig. 1. Formation of ozone reservoir layer and its influence on surface ozone accumulation on the following day. (a) In the afternoon, ozone $\left(\mathrm{O}_{3}\right)$ is uniformly distributed in the convective mixing layer (MD), as revealed by the range of altitudes associated with a constant potential temperature (PT). (b) After sunset, surface cooling forms a nocturnal boundary layer (NBL), and the decay of turbulence within the previous mixing layer forms a residual layer (RL). The RL serves as an ozone reservoir layer (ORL) because ozone levels in this layer can remain as high as that in the previous mixing layer, due to a lack of ozone depleting sources, such as dry deposition and NO titration. (c) The following morning, the ozone in the RL or ORL can be mixed into the growing mixing layer and increasing the surface ozone levels.

transport aloft (Banta et al., 1998; Hidy, 2000). In addition to possibly $\mathrm{O}_{3}$ titration by elevated $\mathrm{NO}$ plumes, nocturnal chemistry, dominated by the nitrate radical, $\mathrm{NO}_{3}$, can also consume ozone, $\mathrm{NO}_{2}+\mathrm{O}_{3} \rightarrow \mathrm{NO}_{3}+\mathrm{O}_{2}$ (Brown et al., 2003; Stutz et al., 2004). Our knowledge of the characteristics of ozone reservoir layers and their effects on daily ozone accumulation is limited.

In this work, four days of complete diurnal and nocturnal variations of vertical ozone and meteorological profiles were obtained from tethered ozone soundings that were intensively performed during a field study during November 2006 in southern Taiwan. The characteristics of the observed ozone reservoir layers, their driving processes and their effects on daily ozone accumulation are investigated and discussed.

\section{Experimental setup}

\subsection{Site description}

Figure 2 shows the location of the study site $\left(22.826^{\circ} \mathrm{N}\right.$, $120.529^{\circ} \mathrm{E}, 10 \mathrm{~m}$ above sea level) and its surroundings. It is a coastal site near mountains, in an agricultural area, $30 \mathrm{~km}$ from the western coastline and $7.5 \mathrm{~km}$ from the eastern edge of the Central Mountain Ranges (CMR). Major sources are located at least $30 \mathrm{~km}$ away from the study site. They include vehicles and industrial parks in and around the industrial Kaohsiung City, and the Shingda (SD) coal-fire power plant $(4300 \mathrm{MW})$ on the western coastline. Pollutants from sources in central or northern Taiwan can also be transported to the study site when ambient flows are northerly. Although 


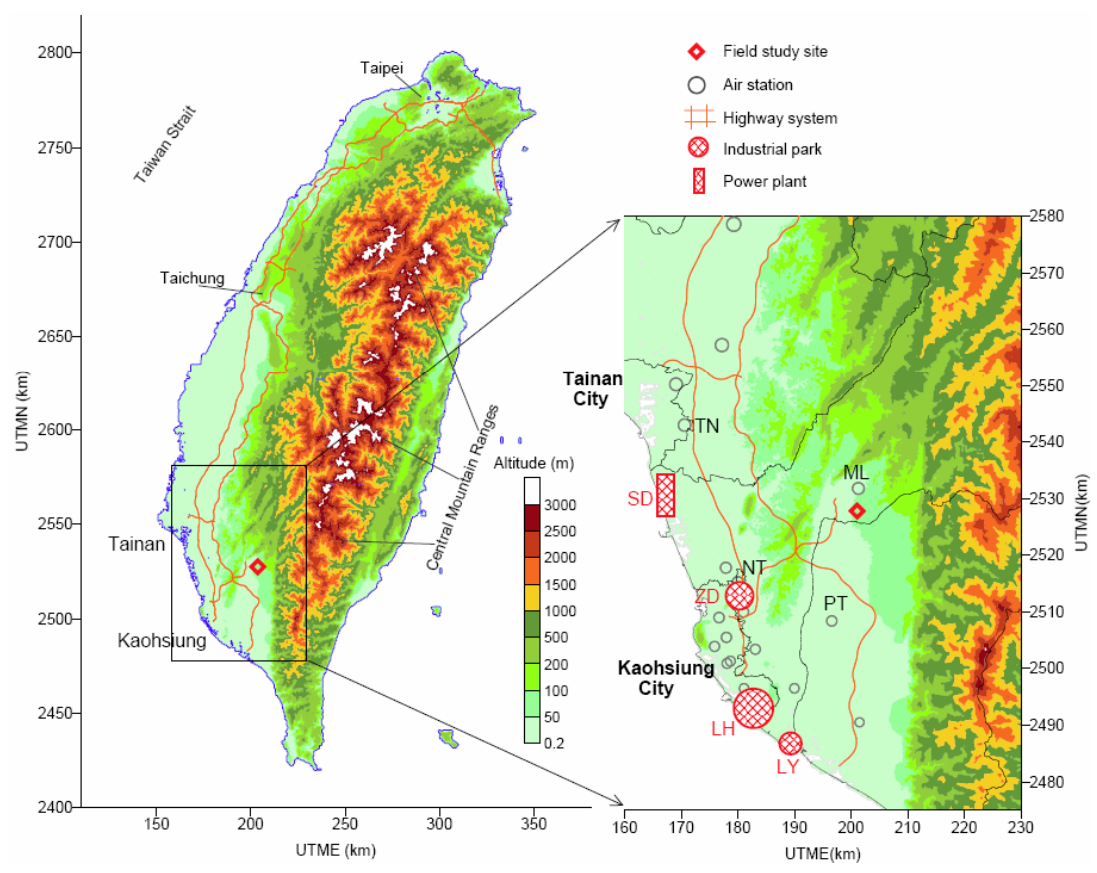

Fig. 2. Topography and location of field study site (diamond) and its surroundings, including air stations, highway systems, industrial parks and the most important power plant (SD) in southern Taiwan.

the main sources are located $30 \mathrm{~km}$ away from the study area, the ozone pollution was unexpectedly high there. For example, in 2006, the Meilung (ML) air station, $7 \mathrm{~km}$ north of the study site, recorded 29 days on which Taiwan's 1-h ozone standard of $120 \mathrm{ppb}$ was violated (Taiwan EPA, 2007).

\subsection{Measurements}

A tethered sounding system was installed at the study site to measure vertical profiles of ozone and other meteorological variables. Our earlier work adopted similar systems (Lin et al., 2004). Tethered soundings were performed daily from 29 October to 12 November 2006 and more frequently during a high-ozone period, 8-11 November. On days of high ozone concentration, soundings were preformed every $2-4 \mathrm{~h}$, up to altitudes of $1400-1600 \mathrm{~m}$ when the meteorological conditions permitted. The system consisted of a helium-filled balloon with a diameter of $3 \mathrm{~m}$, attached to an electric winch via a $2 \mathrm{~km}$-long Kevlar line. Commercial tethered ozonesonde TTO111 (Vaisala, Finland) and meteorological radiosondes TTS111 (Vaisala, Finland) were used to measure simultaneously vertical ozone and meteorological variables (pressure, temperature, relative humidity, wind speed and wind direction). The sondes were tethered on the tethered line, $15 \mathrm{~m}$ below the balloon. The ascent and descent of the balloon were controlled using an electric winch. Both ascending and descending profiles were acquired in each sounding. The ozonesonde sensor was an SPC (Science Pump Corporation, USA) model 6A ECC (Electrochemical Concentration
Cell). A buffered $1 \% \mathrm{KI}$ solution was used in the cathode half-cell and a saturated KI solution was used in the anode half-cell, as suggested by Komhyr (1969) and Komhyr et al. (1995). Before each sounding was conducted, the measurements of the meteorological radiosonde were checked against those measured at an on-site MAWS 201 surface weather station (Vaisala, Finland), which was installed during the field study. Zero and one-point calibrations of the ECC ozonesondes were also performed. The accuracy of the ECC ozonesonde was within $6 \%$ in the lower troposphere (Komhyr et al., 1995).

\subsection{Synoptic weather and surface ozone levels in Taiwan during 8-11 November 2006}

During 8-11 November, the synoptic weather in Taiwan was dominated by a continental anticyclone from mainland China, which was moving eastward (Fig. 3). This synoptic weather pattern along with serious ozone pollution is typical in western Taiwan (Cheng et al., 2001; Chen et al., 2003; Lin et al., 2007). During this period, Taiwan was at the edge of the high-pressure system. The ambient flows toward Taiwan became northeasterly and were blocked by the CMR. Since the solar radiation was sufficiently intense and the ventilation was poor, ozone concentrations quickly increased on 8 November (Fig. 4), and increased further on 9-10 November as the anticyclone moved further eastward and the blocking effect became more important. 


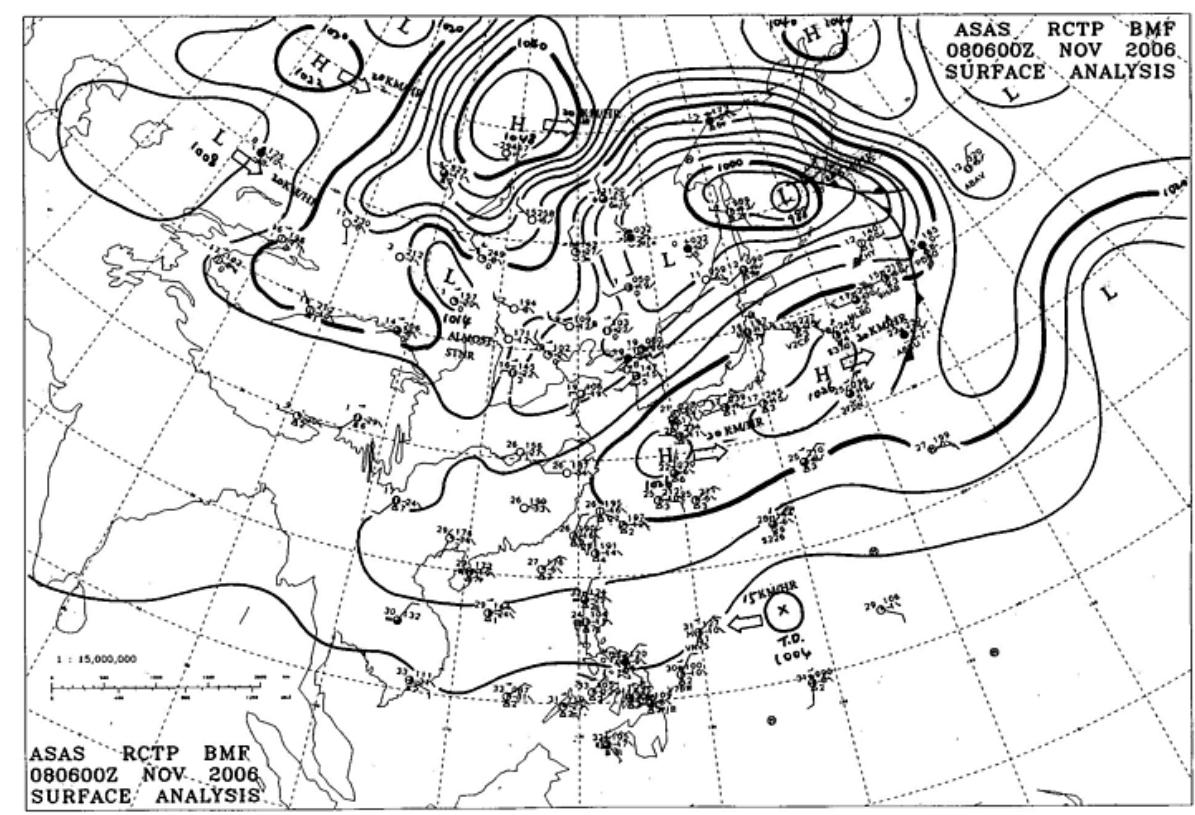

Fig. 3. Synoptic surface weather map on 8 November 2006 (Central Weather Bureau, Taiwan).

On 11 November, a weak front approached Taiwan. The ozone pollution in northern and central Taiwan significantly decreased but in southern Taiwan, the ozone concentrations reached their highest levels within the four-day study period. Figure 4 plots the ozone distributions and wind fields throughout Taiwan in the afternoons from 7 to 12 November, interpolated from the measurements made at the air stations of the Taiwan Air Quality Monitoring Network (TAQMN). From 8 to 11 November, the daily numbers of air stations of the TAQMN that reported violations of the 1-h ozone limit of $120 \mathrm{ppb}$ were 15, 23, 24 and 6. This ozone episode in Taiwan was the most important in 2006.

Ozone pollution is clearly associated with relatively light and landward winds in the afternoon (Fig. 4), suggesting poor ventilation and the development of local circulations. Notably, weak synoptic force actually favored the development of a sea breeze according the previous studies (Atkinson, 1981; Helmis et al., 1987). Daily maximum hourly ozone concentrations reached as low as $40 \mathrm{ppb}$ on $8-10$ November in the upwind northeastern and eastern parts of Taiwan (Fig. 4), suggesting that the ozone episode was not attributable to long-range transport, such as from mainland China (Akimoto et al., 1996; Junker et al., 2009).

Southern Taiwan usually experiences its worst ozone pollution episodes in October or November (autumn) (Chen et al., 2004) but in mid-latitude areas, such as those in the eastern United States and Europe, the worst ozone episodes usually occur in the summer (NRC, 1991). This difference is caused by the fact that the former episodes are caused by a topographical effect, which is the blocking of the CMR (Lin et al., 2007), while the latter are caused by an meteorologi- cal conditions that are conducive to the production of ozone, such as the existence of a slow-moving, high-pressure system (NRC, 1991).

\section{Results and discussion}

\subsection{Daily evolution of ozone reservoir layers}

Figure 5a plots the time-height relationship of each of the ozone soundings and the corresponding number of soundings from 8 to 11 November. A total of 28 soundings were performed over these four days. Figure $5 \mathrm{~b}$ presents some of the ozone profiles to reveal daily cycles in vertical ozone distributions from an afternoon to the following noon. These profiles are the averages of ascending and descending profiles. Hourly vertical ozone distributions are obtained by linearly interpolating all of the measured ozone profiles to clearly reveal continuous variations of vertical ozone concentrations (Fig. 5c).

No distinct elevated ozone layer was observed on the morning of 8 November (Fig. 5c) because the ozone pollution in the previous afternoon was light (Fig. 4). The evolution of the vertical ozone distribution after noon on the last day, 11 November, differed from those on the previous three days. This difference resulted from changes in the wind fields on the morning of 11 November (Fig. 6a).

An ozone reservoir layer is defined herein as a layer of air in which the ozone concentration apparently exceeds the regional background value. Furthermore, the ozone reservoir layer is expected to be present from evening to the next morning below the tops of the daily maximum mixing layers. 


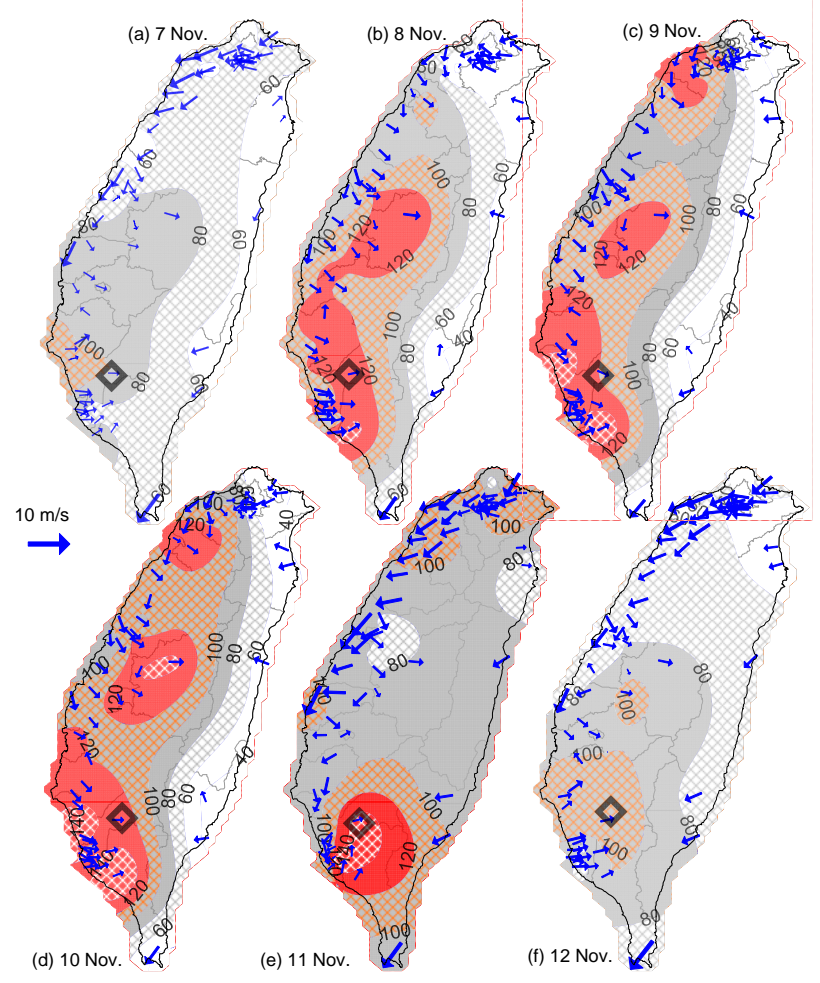

Fig. 4. Daily maximum hourly ozone contours and average wind fields at 12:00-16:00 LT throughout Taiwan, interpolated from the air stations of the Taiwan Air Quality Monitoring Network (TAQMN) during 7-12 November 2006. Diamonds represent the field study site.

The background ozone levels in the free atmosphere during the experimental period were 60-70 ppb, as determined from some soundings that were conducted at relatively high altitudes. Therefore, ozone reservoir layers can be identified as those with ozone concentrations of over $80 \mathrm{ppb}$ from the evening to the next morning. Accordingly, the evolutions of the ozone reservoir layers were quite similar on the three nights between 8 and 11 November (Fig. 5c). The evolution of the ozone reservoir layers on the three nights at the study site can be simply divided into two stages - a developing stage (I) and a stable, descending stage (II) (Fig. 5c). Stage I began at 15:00-17:00 LT, lasted for 5-8 h, and ended at 22:00-23:00 LT. Stage II began at midnight, lasted for 8$10 \mathrm{~h}$, and ended at 08:00-10:00 LT.

Before the beginning of stage I, at 12:00-15:00 LT, vertical ozone concentrations at $0-1300 \mathrm{~m}$ were uniformly distributed, as indicated in ozone profiles nos. 3, 11, and 18 in Fig. $5 b$ and c. The uniformity of the ozone concentration resulted from convective mixing every afternoon. At 15:0017:00 LT daily, surface ozone concentrations reached their daily maximums. Subsequently, a residual layer (RL)-like ozone layer formed.
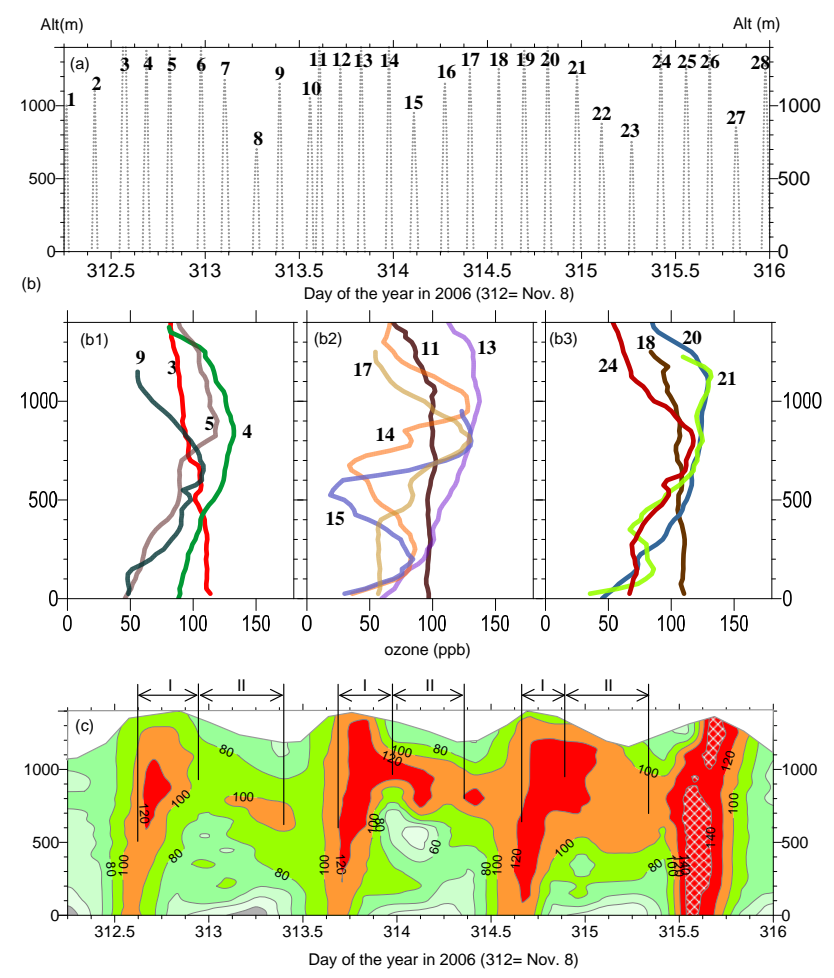

Fig. 5. (a) Time-height relationships of the ozone soundings and the number of soundings from 8 to 11 November 2006, (b) selected ozone profiles associated with numbers of soundings given in (a), and (c) temporal evolution of vertical ozone distributions, produced from linear interpolations of measured ozone profiles in (a). Profiles in (b) are averages of ascending and descending measurements; some upper parts of the ozone contours in (c) are blanked out to avoid false interpolations, due to lack of ozone measurement. Vertical thin lines in (c) represent stages I and II of daily ozone reservoir layer evolutions.

The formation of the RL-like ozone layer marked the beginning of stage I of the daily evolution of the ozone reservoir layer (Fig. 5c). In the first $2-3 \mathrm{~h}$ of stage I, the ozone concentration above the ground increased continuously, particularly from 400 to $1200 \mathrm{~m}$, as indicated in ozone profiles nos. 4, 13 and 20 in Fig. 5b. Thereafter, ozone concentrations at 200$800 \mathrm{~m}$ decreased considerably until midnight (Fig. 5c). However, the ozone concentrations at $800-1200 \mathrm{~m}$ were roughly invariant in the last $3-4 \mathrm{~h}$ of stage I. By midnight, the variations in the vertical ozone distribution had become small and a concentrated, elevated ozone reservoir layer formed at $800-1200 \mathrm{~m}$, as indicated in ozone profiles nos. 5, 14 and 21 in Fig. $5 \mathrm{~b}$ and c. Interestingly, an ozone-depleted air layer was observed at 500-700 m at midnight between 9 and 10 November, as indicated in ozone profiles nos. 14 and 15 in Fig. $5 \mathrm{~b}$ and c. The observed depletion of ozone at elevated levels will be discussed in Sect. 3.2.

In stage II of the daily evolution of the ozone reservoir layers, the vertical ozone distributions were stable but 

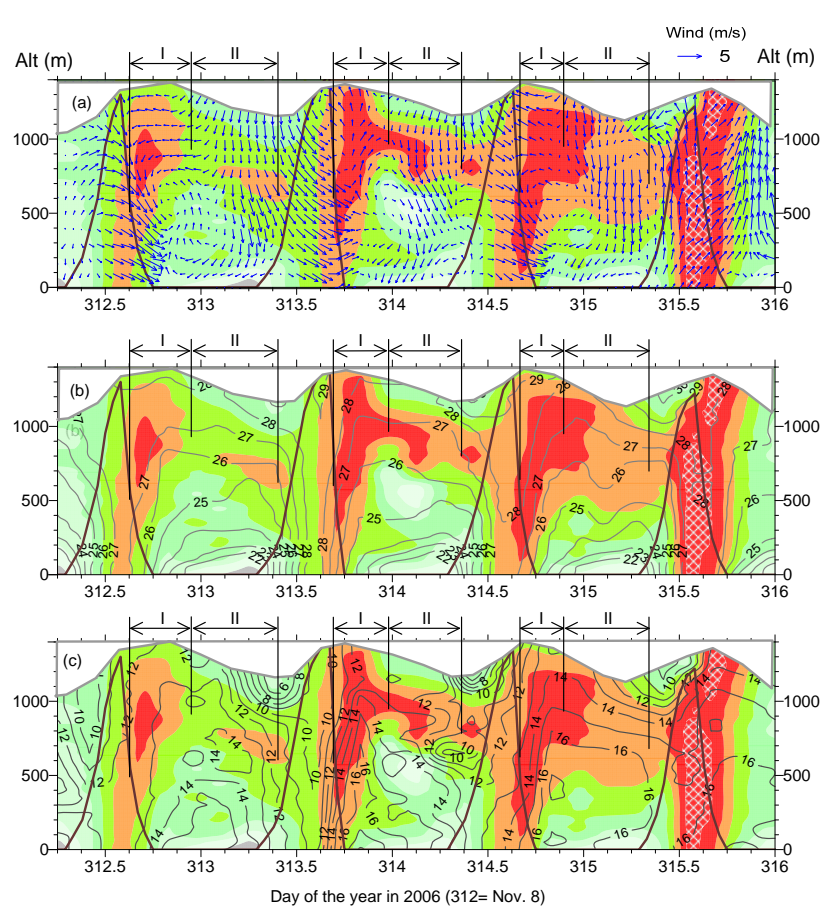

Fig. 6. As Fig. 5c, but for (a) winds, (b) potential temperature in Celsius, and (c) water mixing ratio in $\mathrm{g} / \mathrm{kg}$, superimposed on ozone contours (Fig. 5c). Solid thick lines represent convective mixing layers. Vertical thin lines represent stages I and II of daily ozone reservoir layer evolutions.

the concentrated, elevated ozone layer descended by about $250 \mathrm{~m}$ from $950 \mathrm{~m}$ at midnight to around $700 \mathrm{~m}$ at 09:00 LT in the next morning, as indicated in ozone profiles nos. 9, 17 and 24 in Fig. 5b and c. Finally, the elevated ozone layer merged into the developing mixing layer at 10:00-12:00 LT (Fig. 5c).

Notably, the similarity of the evolution of the daily ozone reservoir layers suggests that the evolution was driven by some regular, daily processes. Furthermore, the observed evolution (Fig. 5b and c) differed from that predicted by the generally accepted model, as presented in Fig. 1. The difference was probably caused by the fact that the evolution in this study was observed in the coastal environment whereas the general model (Fig. 1) was constructed based on experiments conducted inland on a relatively flat continent (Neu et al., 1994; Stull, 1998; Zhang and Rao, 1999). Nighttime transport is expected to be more complicated in a coastal environment than that in a continental one.

\subsection{Processes driving evolution of coastal ozone reservoir layers}

Figure 6 shows the variations of the wind, potential temperature, water mixing ratio, and daytime mixing layer superimposing on ozone contours. Like the ozone concentration (Fig. 5c), these variables are obtained from linear interpolations of these variables from the sounding profiles. The top
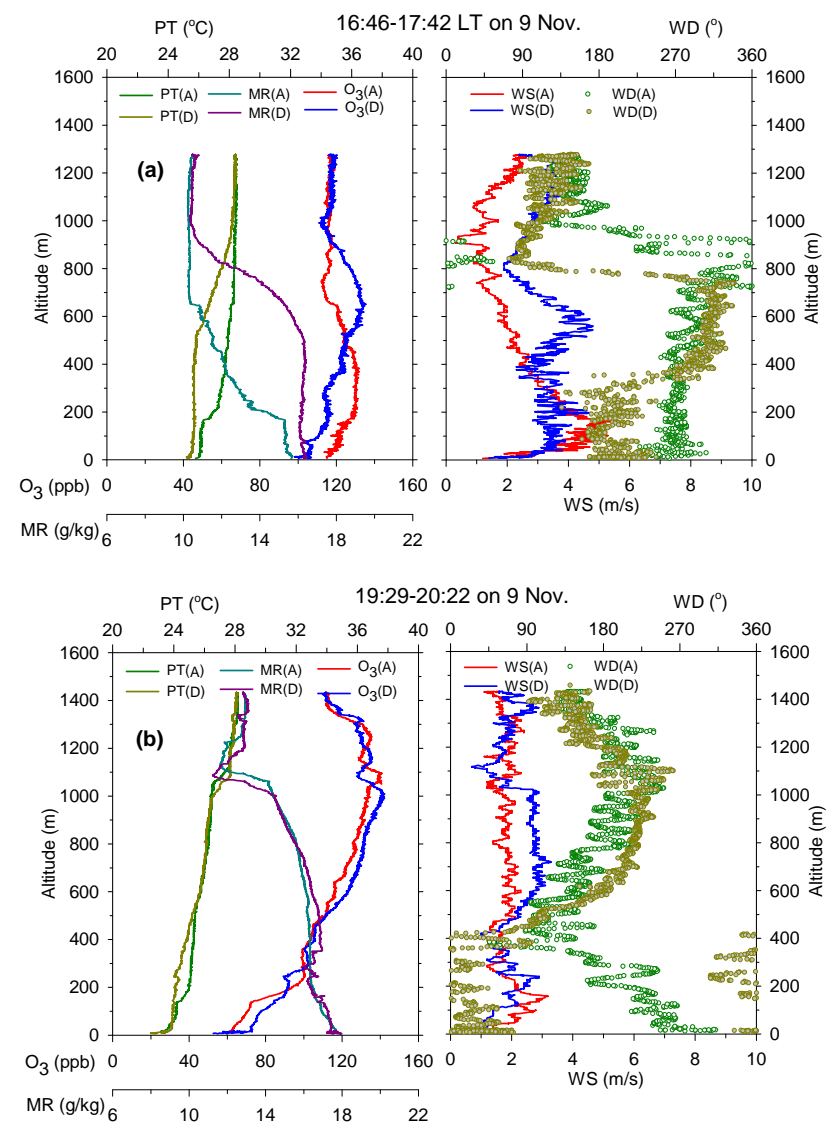

Fig. 7. Vertical profiles of ozone $\left(\mathrm{O}_{3}\right)$, potential temperature $(\mathrm{PT})$, water mixing ratio (MR), wind speed (WS) and wind direction (WD), obtained from tethered soundings at study site at (a) 16:4617:42 LT and (b) 19:29-20:22 LT on 9 November 2006. A and D represent ascending and descending measurements.

of each daytime mixing layer was identified at the altitude where the gradients of potential temperature and water mixing ratio were strong, as suggested by Stull (1988). Figures 7 and 8 show some sounding profiles from the evening of 9 November to the next morning, to elucidate how the relevant factors drive the evolution of the observed ozone reservoir layers.

Backward air trajectories, starting at the study site, were calculated every four hours at altitudes of 200, 400, 600, 800,1000 and $1200 \mathrm{~m}$ to identify the origins of the different air masses that arrived at the study site at different altitudes and times. These back air trajectories were calculated from interpolated wind fields (Fig. 6a), using a method that was described in detail in our previous work (Lin and Chang, 2002; Lin et al., 2004). Banta et al. (1998) employed a similar approach to analyze the city plume transport in Nashville, Tennessee. Figure 9 plots the calculated trajectories at 18:00 and 22:00 LT on 9 November and at 02:00 and 06:00 LT on the next morning to identify typical origins of the air masses at different altitudes in the ozone reservoir layers. 

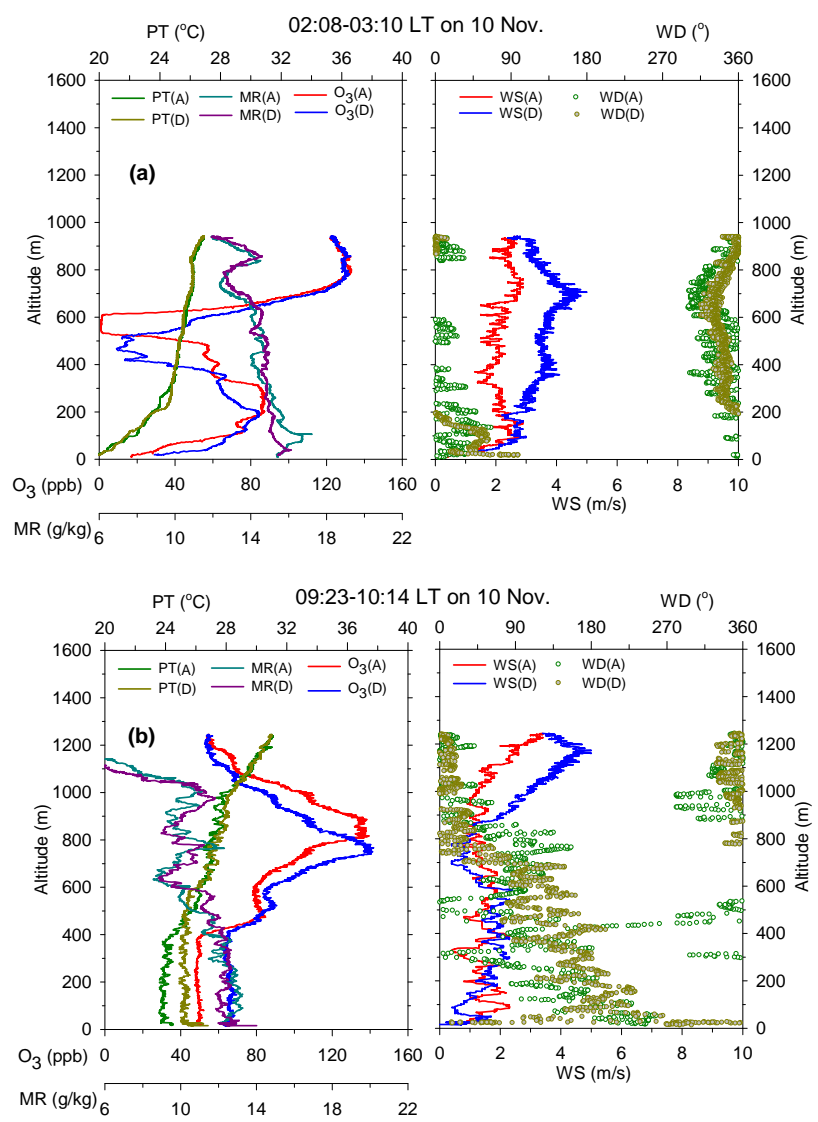

Fig. 8. As Fig. 7, but at (a) 02:08-03:10 LT and (b) 09:23-10:14 LT on 10 November 2006.

Firstly, the formation of the ozone reservoir layers was found to be related to the arrival of cooler marine masses at 15:00-17:00 LT daily. Evidence of the arrival includes rapid decreases in depths of the mixed layers (Fig. 6), decreases in the potential temperature (Fig. 6b), and increases in the water mixing ratio (Fig. 6c). Westerly onshore and easterly offshore winds prevailed below and above the transitional layer; they exhibited the behaviors of sea-breeze circulation (Fig. 6a). The evening sounding of 9 November (Fig. 7a) clearly revealed a rapid decrease in potential temperature and an increase in the water mixing ratio. The decrease in potential temperature and increase in water mixing ratio in Figs. $6 \mathrm{~b}, \mathrm{c}$ and $7 \mathrm{a}$ can be explained by the arrival of cooler, moisture-rich marine air masses.

The rapid decrease in the top of the mixing layer in each afternoon (Fig. 6) resulted from the formation of a stable layer when a cooler marine air mass invaded the bottom part of a warmer mixing layer in the afternoon. The RL-like ozone reservoir layer observed at this time was the residue of the afternoon mixing layer. Notably, the depth of the landward breeze reached $800 \mathrm{~m}$ (Fig. 6a), but only the bottom $200 \mathrm{~m}$ was initially identified as a marine air mass with a relatively low potential temperature and high water mixing

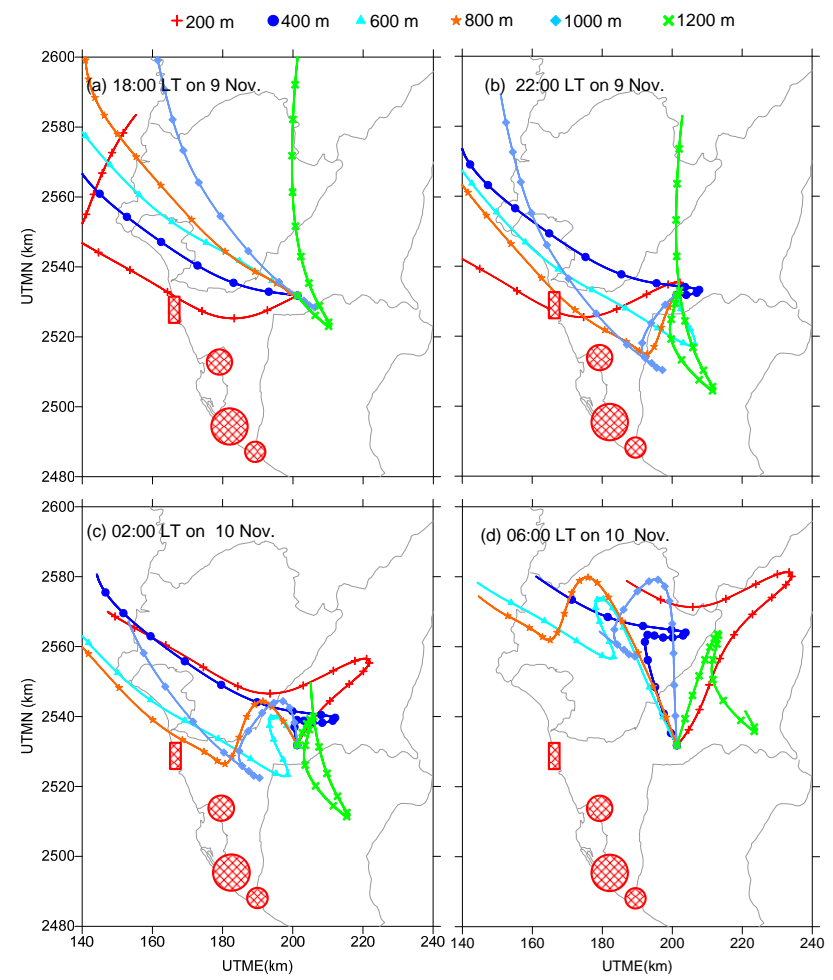

Fig. 9. Back air trajectories at 200, 400, 600, 800, 1000 and $1200 \mathrm{~m}$, starting at study site at (a) 18:00 and (b) 22:00 LT on 9 November, (c) 02:00 and (d) 06:00 LT on 10 November. Distance between adjacent symbols in each trajectory represents one hour; circles and rectangular region indicate locations of industrial parks and SD power plant in southern Taiwan, respectively (Fig. 2).

ratio. Lu and Turco (1994) simulated a similar stabilization of the boundary layer in the evening by an invasion of a cool, marine air mass into an inland, deeper and warmer air mass, in a study of the transport of air pollutants in the Los Angeles Air Basin.

Secondly, initial increase and the subsequent decrease in the ozone concentration in the lower part of the daily ozone reservoir layer below $800 \mathrm{~m}$ in stage I probably resulted from the arrival of more marine air masses at the study site. Notably, the beginning and end of the evolution of the ozone reservoir layers in stage I were consistent with those of the sea-breeze return flow above $800 \mathrm{~m}$. This consistency suggests that the evolution of the ozone reservoir layers in stage I was related to the sea-breeze circulation. This circulation may be a combination of a sea breeze, a mountain flow and their return flows. The combination of a sea breeze and a mountain flow is typical in a coastal mountain region (McKendry and Lundgren, 2000; Whiteman et al., 2000).

Notably, the initially arriving marine air masses were more polluted than those that arrived later because they came from near the coastline where important sources are located. This fact explains why the daily surface ozone concentrations 
were maximal roughly when the marine air masses initially arrived at the study site (Fig. 5c). The continuous increase in ozone concentration at the altitudes $300-800 \mathrm{~m}$ in the first $2-3 \mathrm{~h}$ of stage I is explained by the arrival of polluted coastal air masses at higher altitudes. Notably, the speed of the seabreeze flow peaked at $150 \mathrm{~m}$ and decreased as the altitude increased (Figs. 6a and 7a). Therefore, polluted near-coast air masses at higher altitudes were expected to arrive later than those at lower altitudes.

After the near-coast, polluted air masses had arrived, the marine air masses that arrived subsequently were less polluted, because they came from a more remote, less polluted area over the sea. This fact explains the subsequent, rapid decrease in ozone concentration in the lower part of the ozone reservoir layer toward the end of stage I. The continuous arrival of marine air masses in stage I was evidenced by the continuous decease in potential temperature and increase in water mixing ratio (Fig. $6 \mathrm{~b}$ and c). A backward trajectory analysis also indicated that more marine air masses arrived at the study site in stage I as the night progressed. For example, more air masses came from the sea area at 22:00 LT on 9 November (Fig. 9b) than at 18:00 LT (Fig. 9a). The ozone concentrations at $800-1200 \mathrm{~m}$ remained invariant in stage I because they were polluted, return inland flows, and were initially located within the convective mixing layer (Fig. 6).

Notably, the elevated plumes emitted from large sources in the coastal area may have been accompanied by the marine air masses and transported to the study site when a sea-breeze circulation prevailed. As mentioned in Sect. 3.1, elevated ozone depletion at 500-700 $\mathrm{m}$ was found at night between 9 and 10 November (Fig. $5 b$ and c). Figure 8a depicts one such elevated ozone depletion. Backward trajectories at 22:00 LT on 9 November and 02:00 LT on 10 November (Fig. $9 \mathrm{~b}$ and c) reveal that air masses at several altitudes had previously passed over the coastal, SD power plant, suggesting that the observed ozone depletion resulted from the NO titration within the SD plume, $\mathrm{NO}+\mathrm{O}_{3} \rightarrow \mathrm{NO}_{2}+\mathrm{O}_{2}$. Moreover, the air flow at $400-800 \mathrm{~m}$ frequently blew landward. For example, in the daytime, the flow at $0-800 \mathrm{~m}$ was a landward sea breeze and at night, the flow at 400-1000 was a landward, returning, land breeze. Therefore, the plumes emitted from large coastal point sources, such as the SD power plant (Fig. 8c), can be transported inland both day and night. This previously unnoticed feature may have played an important role in the serious ozone pollution at the inland study area. This effect must be investigated further.

After midnight, the sea-breeze circulation stopped and no more marine air mass arrived subsequently. Hence, the decrease in the ozone concentration in the lower parts of the ozone reservoir layers ceased. The previously easterly, return flows were then replaced with northerly ambient winds (Fig. 6a). However, the direction of the flow changed with altitude. Northeasterly flows typically dominated below $300 \mathrm{~m}$. These were downwardly sloping land breezes, triggered by surface cooling. The flows above the land-flow layer at $400-1000 \mathrm{~m}$ were northwesterly, and probably the counterparts of the land breezes. The backward trajectories at 06:00 LT on 10 November (Fig. 9d) clearly revealed the variation in the flow direction with altitude in stage II. The trajectories also suggest that the elevated, concentrated ozone reservoir layer in stage II came from an area relatively close to the coast. The descent of the daily ozone reservoir layer in stage II was probably the result of atmospheric subsidence due to surface cooling (Fig. 3). This process is common in coastal areas (Simpson, 1994).

During the study period, the synoptic weather was dominated by a high-pressure system (Fig. 3). This high-pressure system may have additionally enhanced the observed strong subsidence. Nighttime subsidence was revealed by the slight increase in potential temperature and the decrease in the water mixing ratio above $500 \mathrm{~m}$ in stage II (Fig. $6 \mathrm{~b}$ and c). However, the transport of air aloft may also mask the subsidence of the elevated ozone reservoir layers. As mentioned above, the air masses at $500-1000 \mathrm{~m}$ came from areas close to the coast. Notably, during the period of prevailing sea-breeze circulation in stage I, the area aloft near the coast was an area of subsidence. As a result, the elevated ozone layers were expected to be relatively low in the near-coast areas. When these lower-level ozone layers were transported to the more inland study site in stage II, they may have masked the subsidence at the site.

\subsection{Conceptual model for coastal ozone reservoir layers}

The observations and above discussion of the ozone reservoir layers suggest that the ozone reservoir layers at the study site were formed by the invasion of cooler, marine air masses into the inland warm, ozone-rich mixing layer. Accordingly, the coastal ozone reservoir layers are expected to have particular characteristics.

An ozone reservoir layer can form at any coastal place where a cooler, marine air mass invades a warm, inland ozone-rich mixing layer. Therefore, the coastal ozone reservoir layer is expected to form over a considerably large coastal region and parallel to the coastline. This region may begin at some distance from the coastline in the sea-land direction and end at the line of penetration of the sea breeze. In a near-coast area, no ozone reservoir layer is expected to form, because a marine air mass may arrive in the area so early that the area does not have enough time to develop a deep, convective mixing layer unless the sea breeze develops late.

The first expectation is supported by the observation of the ozone reservoir layers at the study site during the experimental days. Notably, on the experimental days, the atmosphere was not stagnant but associated with light, northerly ambient flow and sea-land breeze circulations (Fig. 6). Daily formed ozone reservoir layers were, therefore, expected to move and follow those flows. Daily, from the late afternoon to the mid-morning hours of the next day, a period of more 
than $16 \mathrm{~h}$, the observed ozone reservoir layers were expected to move for a considerable distance. However, during this period, ozone reservoir layers were continuously observed at the study site (Fig. 6), suggesting that the horizontal dimension of the ozone reservoir layers was large.

An ozone reservoir layer is expected to form even at a site downwind of a coastal emission area, because the invasion of a marine air mass will not be influenced by the existence of the emission area. However, in this case, the arriving marine air mass can mix with abundant ozone precursors that are emitted from the emission area. Additional ozone can be produced within the arriving marine air mass. Therefore, the ozone concentration in the arriving marine air mass can exceed the marine background level. If a marine air mass is mixed with a large amount of $\mathrm{NO}$ and the site is very close to the emission area, then the ozone concentration in the arriving marine air mass is expected to be lower than the marine background level owing to the titration of ozone by NO.

Finally, when the prevailing wind is strong, no sea breeze will develop. Therefore, the invasion will not occur. Consequently, the formation of an ozone reservoir layer is not expected.

Figure 10 shows a conceptual model of the processes that may drive the evolution of the observed coastal ozone reservoirs. The proposed coastal model and the generally accepted continental one, shown in Fig. 1, have the following differences.

(1) In the coastal model, an ozone reservoir layer is formed by the invasion of a cool, marine air mass into a relatively warm, ozone-rich mixing layer but in the continental model, an ozone reservoir layer is formed by surface cooling after sunset.

(2) A less polluted layer can develop under the coastal ozone reservoir layer because an increasing number of more remote, less polluted marine air masses arrive in the coastal model. However, if the observation site is just downwind of a coastal emission area, then additional ozone may be produced or titrated in the arriving marine air masses. This evolution does not occur in the continental model.

(3) The ozone reservoir layer in the coastal model descends significantly because of nocturnal subsidence. The subsidence is expected to be stronger in the coastal model than in the continental model.

(4) Large increases in surface ozone concentration in the morning due to the downward mixing of the ozone from the ozone reservoir layers probably occur $1-2 \mathrm{~h}$ later in a coastal environment than in a continental one, because the ozone reservoir layer is higher in the former than in the latter. Section 3.4 will elucidate this feature.
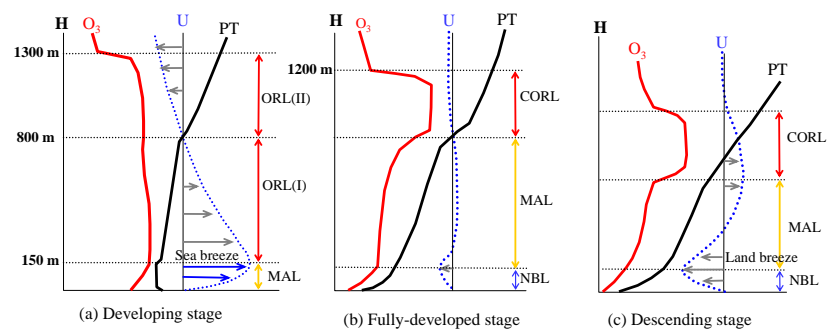

Fig. 10. General evolution of vertical ozone distribution $\left(\mathrm{O}_{3}\right)$, wind $(U)$ and potential temperature (PT) at various stages of the ozone reservoir layer. In the developing stage (a), a cooler, marine air mass arrives at the study site and an ozone reservoir layer forms at altitudes of $150-1300 \mathrm{~m}$ by the invasion of the marine air mass into a warmer, ozone-rich mixing layer. In this stage, the air layer below $150 \mathrm{~m}$, MAL, is filled with marine air. The lower part of the ozone reservoir layer at $150-800 \mathrm{~m}$, ORL(I), is a sea-breeze-like layer. However, it is filled with air masses that originate over land. The upper part of the ozone reservoir layer at 800-1300 m, ORL(II), is a return-flow layer that is filled with air masses that originated inland. The fully-developed stage is associated with the stopping of sea-breeze circulation by midnight when (b) a concentrated, elevated ozone reservoir layer, CORL, forms at $800-1200 \mathrm{~m}$, and is filled with air masses that originated inland. The air layer in the previous ORL(I) is now filled with recently-arrived, less polluted marine air masses, MAL. Additionally, a stable nocturnal boundary layer (NBL) is formed by surface cooling. The descending stage is from midnight to the following morning (c). A land-breeze circulation is fully developed. The CORL gradually descends and the previous MAR becomes shallow owing to nocturnal subsidence.

\subsection{Ozone carried over from the preceding day and ozone produced on the current day}

Ozone that was observed in the early-morning ozone reservoir layers (Fig. 5c) was carried over from the preceding day. This ozone enhanced surface ozone concentration by downward mixing, while the daytime mixing layers grew through the ozone reservoirs. The daily morning soundings conducted during the field study revealed this phenomenon. Figure $8 b$ shows such an example.

Clearly, an ozone concentration in a daily mixing layer (which is the total ozone concentration, $C_{\text {tot }}$ ) consists of two parts. The first part is carried over from the preceding day (old ozone concentration, $C_{\text {old }}$ ) and the second is produced on the current day (new ozone concentration, $C_{\text {new }}$ ). Information on the relative contributions of $C_{\text {old }}$ and $C_{\text {new }}$ to $C_{\text {tot }}$ are important for air quality managers to construct effective strategies for controlling ozone pollution. This section proposes an observation-based method, which is adopted to estimate hourly variations of $C_{\text {old }}$ and $C_{\text {new }}$ during the daytime on the four experimental days.

First, the old and new ozone in a daytime mixing layer are assumed to be independent of each other. Based on this assumption, the processes that dominate the local variation in 
the old ozone concentration can be expressed by an equation that is similar to Eq. (1),

$$
\begin{aligned}
\frac{\partial C_{\text {old }}}{\partial t} & +\left(U \frac{\partial C_{\text {old }}}{\partial x}+V \frac{\partial C_{\text {old }}}{\partial y}\right)=\left(P_{\text {old }}-L_{\text {old }} C_{\text {old }}\right)-C_{\text {old }} \frac{v_{d}}{h} \\
& +\left(C_{r}-C_{\text {old }}\right) \frac{1}{h} \frac{\partial h}{\partial t}
\end{aligned}
$$

where the sub index "old" represents the old ozone. Notably, all observations in this investigation were made at a fixed location, the study site, but not made within a traveling air parcel. Therefore, Eq. (2) should be expressed in an Euler form but not in a Lagrangian form. The terms of horizontal transport and the net chemical production in Eq. (2) are neglected, enabling the hourly variations in the old ozone concentration at the study site during the four experimental days to be successfully estimated using the observed mixing heights and vertical ozone profiles. The possible uncertainties associated with neglecting the two terms are discussed below.

Apparently, the horizontal transport term in Eq. (2) has only a small effect when the wind is light and/or the horizontal gradient of the old ozone concentration is small, or when the transport term is smaller than the other terms. Light winds within the mixing layers were found from sunrise to noon on the four experimental days (Fig. 6). The net entrainment term was also expected to dominate the overall variation of the old ozone concentration in the late morning hours. Therefore, neglecting the horizontal transport term in Eq. (2) in this study was expected to have only a small effect in the morning hours.

The observed ozone reservoirs were expected to have a large horizontal dimension, as discussed in Section 3.3. The horizontal gradient of the old ozone concentration was small when the study site was under the moving ozone reservoir layers. The arrival of relatively clean marine air masses at the study site in the late afternoon daily probably indicates that the edges of the ozone reservoir layers at the seaward side had probably just passed over. Therefore, neglecting the horizontal transport term may generate relatively large uncertainties after the arrival of the marine air masses at the study site, typically late in the afternoons.

The net chemical production above the mixing layer should be trivial owing to the lack of reactive species there. When the old ozone came into contact with newly emitted species, such as NO and VOCs, within the mixing layers, the old ozone may have been depleted and $\mathrm{NO}_{2}$ and some peroxide radicals produced in. However, the produced $\mathrm{NO}_{2}$ and peroxide radicals are expected to have reproduced new ozone in a short period, as described by NRC (1991). The chemical production and loss rates were, therefore, roughly the same for the old ozone, indicating that neglecting the net chemical production in Eq. (2) is acceptable.

When the horizontal transport and net chemical production terms are neglected, the processes that govern the rate of variation of the old ozone concentration in a daytime mixing layer can be described simply by

$\frac{\partial C_{\text {old }}}{\partial t}=-C_{\text {old }} \frac{v_{d}}{h}+\left(C_{r}-C_{\text {old }}\right) \frac{1}{h} \frac{\partial h}{\partial t}$

The following finite-difference equation is further used to determine the hourly variations of the old ozone concentration:

$$
\begin{aligned}
& \frac{C_{\text {old }}^{n}-C_{\mathrm{old}}^{n-1}}{1}=-C_{\mathrm{old}}^{n-1} \frac{v_{d}}{h^{n-1 / 2}} \\
& +\left(C_{r}^{n-1}-C_{\mathrm{old}}^{n-1}\right) \frac{1}{h^{n-1 / 2}} \frac{h^{n}-h^{n-1}}{1}
\end{aligned}
$$

where the upper index $n$ represents the $n$th hour. In this study, the dry deposition velocity $v_{d}$ is assumed to increase linearly from $0.2 \mathrm{~cm} / \mathrm{s}$ at 07:00 LT to $0.4 \mathrm{~cm} / \mathrm{s}$ at 12:00 LT and to decrease linearly from $0.4 \mathrm{~cm} / \mathrm{s}$ at $13: 00 \mathrm{LT}$ to $0.2 \mathrm{~cm} / \mathrm{s}$ at 18:00 LT. These values are typical of agricultural areas during the fall (Wesely and Hicks, 2000). Notably, the last net entrainment term should be ignored when the mixing layer is falling, typically in the afternoon, because in that situation, no entrainment or dilution can occur.

Rearranging Eq. (4) yields the equation for estimating the hourly concentrations of the old ozone,

$C_{\text {old }}^{n}=C_{\text {old }}^{n-1}\left(1-\frac{v_{d}}{h^{n-1 / 2}}-\frac{h^{n}-h^{n-1}}{h^{n-1 / 2}}\right)+C_{r}^{n-1} \frac{h^{n}-h^{n-1}}{h^{n-1 / 2}}$

or

$C_{\text {old }}^{n}=C_{\text {old }}^{n-1}\left(1-\frac{v_{d}}{h^{n-1 / 2}}\right)$

where Eqs. (5) and (6) apply for the hours when the mixing layer is growing and falling, respectively.

The initial hour to estimate the concentration of the old ozone in Eqs. (5-6) is set at 06:00 LT daily. At such early hour, solar radiation is very weak and, therefore, no new ozone is produced. Consequently, the concentration of the old ozone at 06:00LT, $C_{\text {old }}^{6}$, can be easily obtained from the observed concentration of the total ozone at 06:00 LT:

$C_{\mathrm{old}}^{6}=C_{\mathrm{tot}}^{6}$

Finally, Eqs. (5-7) are used to calculate the hourly concentrations of the old ozone in the daytime mixing layers on the four experimental days.

The processes that dominate the hourly variations of the new ozone in a daytime mixing layer can be expressed by an equation that is similar to Eq. (2) as,

$$
\begin{aligned}
\frac{\partial C_{\text {new }}}{\partial t} & +\left(U \frac{\partial C_{\text {new }}}{\partial x}+V \frac{\partial C_{\text {new }}}{\partial y}\right)=\left(P_{\text {new }}-L_{\text {new }} C_{\text {new }}\right) \\
& -C_{\text {new }} \frac{v_{d}}{h}+\left(-C_{\text {new }}\right) \frac{1}{h} \frac{\partial h}{\partial t}
\end{aligned}
$$

where the sub index "new" represents the new ozone. Notably, the last net entrainment term on the right-hand side of Eq. (8) includes only the dilution effect since the concentration of the new ozone in the ozone reservoir layer is assumed 
to be close to zero. Notably, the net chemical production term in Eq. (8) is expected to dominate the local variation of the new ozone during most of the daytime. The horizontal transport term in Eq. (8) may also be very important because the sea-breeze flow can transport the new ozone from the coastal emission area to the study site, as discussed in Sect. 3.2. Therefore, neglecting the above two terms and determining the hourly concentrations of the new ozone in a manner similar to that adopted for the old ozone concentration is unreasonable. The following paragraph proposes an approach that overcomes this difficulty.

The hourly concentration of the new ozone can be estimated simply by subtracting the hourly concentration of the old ozone, estimated using Eqs. (5-7), from the total ozone concentration, which was continuously monitored at the study site during the study period:

$C_{\text {new }}^{n}=C_{\text {tot }}^{n}-C_{\text {old }}^{n}$

Equation (9) is finally used to estimate the hourly concentration of the new ozone concentration in the daytime mixing layers at the study site on the four experimental days. Notably, the uncertainties associated with the concentration of the new ozone estimated using Eq. (9) are only related the uncertainties associated the estimation of the concentration of the old ozone. Actually, all processes that are likely to affect the hourly variations of the new ozone concentration, as expressed in Eq. (8), are implicitly accounted for when they are estimated using Eq. (9). Relatively large uncertainties associated with the calculation of the new ozone concentration may appear in the late afternoon because in this period the uncertainties associated with the calculation of the old ozone concentration may become large as mentioned above.

Figure 11 plots hourly concentrations of the total ozone concentration, the estimated new ozone concentration, the estimated old ozone concentration, and the rates of their hourly variations at the study site on the four experimental days, obtained using Eqs. (5-7) and (9). Hourly concentrations of the total ozone and old ozone follow each other very closely from 06:00 to 12:00 LT daily, suggesting that the increase of the total ozone concentration in the morning hours is dominated by the old ozone. The hourly concentrations of the total ozone increase continuously from 12:00 to 17:00 LT daily. During this period, the old ozone concentration does not increase, and the increase in the total ozone concentration is the same as that of the new ozone concentration, suggesting that the increase of the total ozone concentration in the afternoon is dominated by the new ozone.

On the four experimental days, the daily maximum hourly rates of increase of the total ozone, old ozone and new ozone concentrations are in the ranges 16-30, 12-24, and $10-16 \mathrm{ppb} / \mathrm{h}$, respectively. The three rates of increase are all highest in the morning hours. The hourly rate of increase of the total ozone concentration (Fig. 11) exhibits two peaks at around 8 and 11:00-12:00 LT daily. The first daily peak
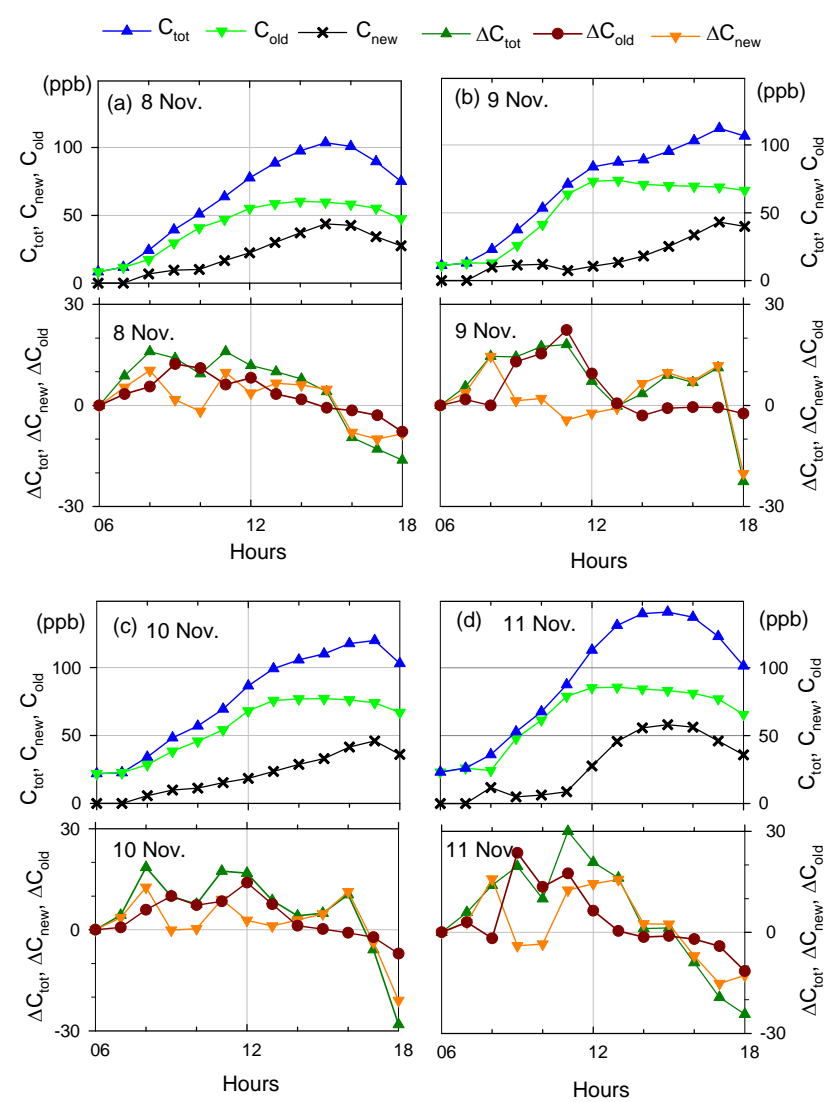

Fig. 11. Hourly variations of the total ozone concentration $\left(C_{\text {tot }}\right)$, new ozone concentration $\left(C_{\text {new }}\right)$, and old ozone concentration $\left(C_{\text {new }}\right)$ and their rates of hourly variation $\Delta C_{\text {tot }}, \Delta C_{\text {new }}$, and $\Delta C_{\text {old }}$, respectively, at the study site during the daytime on the four experimental days.

at 08:00 LT is coincident with greatly increased concentration of the new ozone. This first peak results from the high rate of production of ozone in the shallow, morning mixing layer. Notably, the concentrations of ozone precursors can be very high in the morning, shallow mixing layers since ozone precursors that are emitted at night are confirmed near the ground by surface inversion. The second peak at 11:0012:00 LT is associated with greatly increased concentration of the old ozone (Fig. 11). The second peak arises when mixing layers grow through the concentrated ozone reservoir layers at 500-900 m (Fig. 6). Therefore, the second peak results from the downward mixing of the old ozone from the ozone reservoir layers.

The increase in the new ozone concentration in the daytime mixing layer may have resulted from the horizontal transport and net chemical production, as indicated in Eq. (8). On 9 and 10 November, the late-afternoon peaks in the hourly rate of increase of the new ozone concentration are found. In the late afternoons, chemical productions should be small because solar intensity is weak. Therefore, 
the late-afternoon increases are caused by a sea breeze, which can transport the new ozone from the coastal polluted area to the study site.

In rural areas, the downward mixing of old ozone from ozone reservoir layers can reportedly dominate daytime ozone increases (Kleinman et al., 1994; Niccum et al., 1995). The contribution of old ozone to a daily ozone increase in a polluted area has seldom been reported. New ozone can be reasonably assumed to dominate daily ozone increases in a polluted area since ozone precursors are abundant there. However, our investigation indicates that even in a polluted area such as southern Taiwan, the contribution of old ozone through downward mixing process to total ozone can be $50 \%$ more important than that of ozone newly produced on that day. The daily maximum hourly concentrations of total ozone on the four experimental days were in the range 103$141 \mathrm{ppb}$, with an average of $119 \mathrm{ppb}$; those of the old ozone were in the range $60-85 \mathrm{ppb}$, with an average of $74 \mathrm{ppb}$, and those of the new ozone were in the range 43-58 ppb, with an average of $48 \mathrm{ppb}$. On average, the contributions of the old ozone and the new ozone to the total ozone were 60 and $40 \%$, respectively. Accordingly, more attention should be paid to old ozone in studies of ozone pollution.

\section{Conclusions}

Previous experimental investigations have found that a relatively stable ozone reservoir layer can form over homogenous, continental land owing to surface cooling after sunset. This study reveals that an ozone reservoir layer can also form over an extended coastal inland region, but by a process other than surface cooling. The coastal ozone reservoir layer is dynamic but not stable in the nocturnal atmosphere.

The coastal ozone reservoir layer observed in this work was initially formed by the invasion of a cool, marine air mass into a relatively warm, ozone-rich mixing layer. The subsequent evolution of the ozone reservoir layer includes a developing stage and a stable, descending stage, as observed at the study site. During the developing stage, typically from late afternoon to midnight, a less polluted layer becomes deeper under the initially formed ozone reservoir layer because an increasing number of more remote, less polluted marine air masses arrive. Finally, an elevated ozone reservoir layer forms after sea-breeze circulations stop around midnight. For the rest of the night, the elevated ozone reservoir layer gradually descends due to nocturnal subsidence.

The downward mixing of ozone is normally expected to dominate a surface ozone accumulation at 08:00-10:00 LT when surface inversion is interrupted. However, in this study, a later and more important contribution to the surface ozone accumulation is made at 11:00-12:00 LT, because the concentrated ozone reservoir layer is higher in a coastal environment than in an inland environment. This finding suggests that the effect of downward mixing on surface ozone con- centration is related to the vertical distribution of the ozone in an ozone reservoir layer. Furthermore, ozone distributions within the ozone reservoir layers are expected to be far from uniform, as presented in Fig. 1, particularly where local circulations dominate, as described in the current work.

Since a sea-breeze circulation is much deeper than a landbreeze circulation, large point sources in a coastal region may contribute substantially to inland ozone pollution, because the plumes of coastal point sources can be transported inland accompanied by a landward, sea-breeze flow in the daytime and, accompanied by a landward, returning land-breeze flow at night. This scenario is worthy of further study.

Finally, results of this work suggest that even in an area of high pollution and on a day of an ozone episode, the downward mixing of ozone or the ozone from the preceding day can still contribute $50 \%$ more to daily ozone pollution than the ozone produced on the day of interest. Further understanding ozone reservoir layers is critical, and will depend on the future simulation-based and experimental investigations.

Acknowledgements. The authors would like to thank the National Science Council (Contract No. NSC 95-2221-E-242-012) and the Environmental Protection Administration (EPA 95-FA11-03-D087) of the Republic of China, Taiwan, for financially supporting this research.

Edited by: C. K. Chan

\section{References}

Akimoto, H., Mukai, H., Nishikawa, M., Murano, K., Hatakeyama, S., Liu, C. M., Buhr, M., Hsu, K. J., Jaffe, D. A., Zhang, L., Honrath, R., Merrill, J. T., and Newell, R. E.: Long-range transport of ozone in the East Asian Pacific rim region, J. Geophys. Res., 101(D1), 1999-2010, 1996.

Atkinson, B. W.: Mesoscale Atmospheric Circulations. Academic Press, 495 pp., 1981.

Banta, R. M., Senff, C. J., White, A. B., Trainer, M., McNider, R. T., Valente, R. J., Mayor, S. D., Alvarez, R. J., Hardesty, R. M., Parrish, D., and Fehsenfeld, F. C.: Daytime buildup and nighttime transport of urban ozone in the boundary layer during a stagnation episode, J. Geophys. Res., 103(D17), 22519-22544, 1998.

Baumann, K., Williams, E. J., Angevine, W. M., Roberts, J. M., Norton, R. B., Frost, G. J., Fehsenfeld, F. C., Springston, S. R., Bertman, S. B., and Hartsell, B.: Ozone production and transport near Nashville, Tennessee: Results from the 1994 study at New Hendersonville, J. Geophys. Res., 105(D7), 9137-9153, 2000.

Brown, S. S., Stark, H., Ryerson, T. B., Williams, E. J., Nicks Jr., D. K., Trainer, M., Fehsenfeld, F. C., and Ravishankara, A. R.: Nitrogen oxides in the nocturnal boundary layer: Simultaneous in situ measurements of $\mathrm{NO}_{3}, \mathrm{~N}_{2} \mathrm{O}_{5}, \mathrm{NO}_{2}$, NO, and $\mathrm{O}_{3}$, J. Geophys. Res., 108(D9), 4299, doi:10.1029/2002JD002917, 2003.

Cantrell, C. A., Shetter, R. E., Gilpin, T. M., Calvert, J. G., Eisele, F. L., and Tanner, D. J.: Peroxy radical concentrations measured and calculated from trace gas measurements in the Mauna Loa Observatory Photochemistry Experiment 2, J. Geophys. Res., 101(D9), 14653-14664, 1996. 
Cardelino, A. C. and Chameides, W. L.: The application of data from photochemical assessment monitoring stations to observation-based model, Atmos. Environ., 34, 2325-2332, 2000.

Chen, K. S., Ho, Y. T., Lai, C. H., and Chou, Y. M.: Photochemical modeling and analysis of meteorological parameters during ozone episodes in Kaohsiung, Taiwan, Atmos. Environ., 37, 1811-1823, 2003.

Chen, K.-S., Ho, Y. T., Lai, C. H., and Tsai, Y. A.: Trends in concentration of ground-level ozone and meteorological conditions during high ozone episodes in Kao-ping Airshed, Taiwan, J. Air Waste Manage. Assoc., 54, 36-48, 2004.

Cheng, W. L., Pai, J. L., Tsuang, B. J., and Chen, C. L.: Synoptic patterns in relation to ozone concentrations in west-central Taiwan, Meteorol. Atmos. Phys., 78, 11-21, 2001.

Dabberdt, W. F., Carroll, M. A., Baumgardner, D., Carmichael, G., Cohen, R., Dye, T., Ellis, J., Grell, G., Grimmond, S., Hanna, S., Irwin, J., Lamb, B., Madronich, S., McQueen, J., Meagher, J., Odman, T., Pleim, J., Schmid, H. P., and Westphal, D. L.: Meteorological research needs for improved air quality forecasting - Report of the 11th prospectus development team of the US Weather Research Program, B. Am. Meteorol. Soc., 85, 563586, 2004

Evans, M. J., Shallcross, D. E., Lawa, K. S., Wild, J. O. F., Simmonds, P. G., Spain, T. G., Berrisford, P., Methven, J., Lewis, A. C., McQuaid, J. B., Pilling, M. J., Bandy, B. J., Penkett, S. A., and Pyle, J. A.: Evaluation of a Lagrangian box model using field measurements from EASE (Eastern Atlantic Summer Experiment) 1996, Atmos. Environ., 34, 3843-3863, 2000.

Frost , G. J., Trainer, M., Allwine, G., Buhr, M. P., Calvert, J. G., Cantrell, C. A., Fehsenfeld, F. C., Goldan, P. D., Herwehe, J., Hübler, G., Kuster, W. C., Martin, R., McMillen, R. T., Montzka, S. A., Norton, R. B., Parrish, D. D., Ridley, B. A., Shetter, R. E., Walega, J. G., Watkins, B. A., and Westberg, H. H.: Photochemical ozone production in the rural southeastern United States during the 1990 Rural Oxidants in the Southern Environment (ROSE) program, J. Geophys. Res., 103(D17), 2249122508, 1998.

Fuhrer, J.: Agroecosystem responses to combinations of elevated $\mathrm{CO}_{2}$, ozone, and global climate change, Agr. Ecosyst. Environ., 97, 1-20, 2003

Gerasopoulos, E., Kouvarakis, G., Vrekoussis, M., Donoussis, C., Mihalopoulos, N., and Kanakidou, M.: Photochemical ozone production in the Eastern Mediterranean, Atmos. Environ., 40, 3057-3069, 2006.

Hidy, G. M.: Ozone process insights from field experiments Part I: Overview, Atmos. Environ., 34, 2001-2022, 2000.

Helmis, C. G., Asimakopoulos, D. N., Deligiorgi, D. G., and Lalas, D. P.: Observations of sea-breeze fronts near the shoreline, Bound. Lay. Meteorol., 38, 395-410, 1987.

Junker, C., Wang, J. L., and Lee, C. T.: Evaluation of the effect of long-range transport of air pollutants on coastal atmospheric monitoring sites in and around Taiwan, Atmos. Environ., 43, 3374-3384, 2009.

Kleinman, L. I.: Photochemical formation of peroxides in the boundary layer, J. Geophys. Res., 91, 10889-10904, 1986.

Kleinman, L., Lee, Y.-N., Springston, S. R., Nunnermacker, L., Zhou, X., Brown, R., Hallock, K., Klotz, P., Leahy, D., Lee, J. H., and Newman, L.: Ozone formation at a rural site in the
Southeastern United States, J. Geophys. Res., 99, 3469-3482, 1994.

Komhyr, W. D.: Electrochemical concentration cells for gas analysis, Ann. de Geophysique, 25, 203-210, 1969.

Komhyr, W. D., Barnes, R. A., Brothers, G. B., Lathrop, J. A., and Opperman, D. P.: Electrochemical concentration cell ozonesonde performance evaluation during STOIC 1989, J. Geophys. Res., 100, 9231-9244, 1995.

Lin, C.-H. and Chang, L.-F. W.: Relative source contribution analysis using an air trajectory statistical approach. J. Geophys. Res. 107, 4583-4592, 2002.

Lin, C.-H, Wu, Y.-L., Lai, C.-H., Lin, P.-H., Lai, H.-C., and Lin, P.L.: Experimental investigation of ozone accumulation overnight during a wintertime ozone episode in south Taiwan, Atmos. Environ., 38, 4267-4278, 2004.

Lin, C. Y., Wang, Z., Chou, C. C. K., Chang, C. C., and Liu, S. C.: A numerical study of an autumn high ozone episode over southwestern Taiwan, Atmos. Environ., 41, 3684-3701, 2007.

Lu, R. and Turco, R. P.: Air pollutant transport in a coastal environment. II: Three-dimensional simulations over Los Angeles basin, Atmos. Environ., 29, 1499-1518, 1995.

McKendry, I. G. and Lundgren, J.: Tropospheric layering of ozone in regions of urbanized complex and/or coastal terrain: a review, Prog. Phys. Geogr., 24, 329-354, 2000.

National Research Council (NRC): Rethinking the Ozone Problem in Urban and Regional Air Pollution, National Academy Press, Washington, District of Columbia, 1991.

Neu, U., Kunzle, T., and Wanner, H.: On the relation between ozone storage in the residual layer and daily variation in near-surface ozone concentration - A case study, Bound.-Lay. Meteorol., 69, 221-247, 1994.

Niccum, E. M., Lehrman, D. E., and Knuth, W. R.: The influence of meteorology on the air quality in the San Luis Obispo CountySouthwestern San Joaquin Valley Region for 3-6 August 1990. Special Issue for the Regional Photochemical Measurement and Modeling Studies Specialty Conference, J. Appl. Meteorol., 34, 1834-1847, 1995.

Placet, M., Mann1, C. O., Gilbert, R. O., and Niefer, M. J.: Emissions of ozone precursors from stationary sources: a critical review, Atmos. Environ., 34, 2183-2204, 2000.

Russell, A. and Dennis, R.: NARSTO critical review of photochemical models and modeling, Atmos. Environ., 34, 2283-2324, 2000.

Shiu, C. J., Liu, S. C., Chang, C.C., Chen, J. P., Chou, C. C. K., Lin, C. Y., and Young, C.Y.: Photochemical production of ozone and control strategy for Southern Taiwan, Atmos. Environ., 41, 9324-9340, 2007.

Simpson, J. E.: Sea Breeze and Local Winds, Cambridge University Press, UK, 1994.

Spirig, C., Neftel, A., Kleinman, L. I., and Hjorth, J.: $\mathrm{NO}_{\mathrm{x}}$ versus VOC limitation of $\mathrm{O}_{3}$ production in the Po valley: Local and integrated view based on observations, J. Geophys. Res., 107(D22), 8191, doi:10.1029/2001JD000561, 2002.

Stull, R. B.: An Introduction to Boundary Layer Meteorology, Kluwer Academic, London, 1998.

Stutz, J., Alicke, B., Ackermann, R., Geyer, A., White, A., and Williams, E.: Vertical profiles of $\mathrm{NO}_{3}, \mathrm{~N}_{2} \mathrm{O}_{5}, \mathrm{O}_{3}$, and $\mathrm{NOx}$ in the nocturnal boundary layer: 1. Observations during the Texas Air Quality Study 2000, J. Geophys. Res., 109, D12306, 
doi:10.1029/2003JD004209, 2004.

Taiwan EPA: Air Quality Annual Report, 2006. Taiwan Environment Protection Administration, Taipei, Taiwan, 2007.

Trainer, M., Buhr, M. P., Curran, C. M., Fehsenfeld, F. C., Hsie, E. Y., Liu, S. C., Norton, R. B., Parrish, D. D., Williams, E. J., Gandrud, B. W., Ridley, B. A., Shetter, J. D., Allwine, E. J., and Westberg, H. H.: Observations and Modeling of the Reactive Nitrogen Photochemistry at a Rural Site, J. Geophys. Res., 96(D2), 3045-3063, 1991.

Trainer, M., Parrish, D. D., Goldan, P. D., Roberts, J., and Fehsenfeld, F. C.: Review of observation-based analysis of the regional factors influencing ozone concentrations, Atmos. Environ., 34, 2045-2061, 2000.
Wesely, M. L. and Hicks, B. B.: A review of the current status of knowledge on dry deposition, Atmos. Environ., 34, 2261-2282, 2000.

Whiteman, C. D., Zhong, S., Bian, X., Fast, J. D., and Doran, J. C.: Boundary layer evolution and regional-scale diurnal circulations over the Mexican plateau, J. Geophys. Res., 105(D8), 1008110102, 2000.

Zhang, J. and Rao, S. T.: On the role of vertical mixing in the temporal evolution of ground-level zone concentrations, J. Appl. Meteorol., 38, 1674-1691, 1999. 